idea without due credit, and partly because I am gratified that a thought which has lain long in my mind is now confirmed by so eminent a biologist and so profound a thinker as Dr. Weissmann.

2. There is one point, however, in Dr. Weissmann's paper, to which I would take some slight exception. He says, "There is no essential, but only individual differences between the nuclear substance of the spermatozoön and of the ovum. There are no such things as male and female nuclear substances, but only male and female cells, carriers of immortal germ plasm." Now, if by 'essential differences' he means mysterious or occult differences, such as are usually attributed to sex, he is probably right ; but surely sexual reproduction is a device of nature whereby greater individual differences of nuclear substances are produced than could have been gotten in any other way. Such extreme individual differences are called 'sexual' in the case of organisms : why not also in the case of nuclear substances?

3. In the other paper referred to, Hatschek, after criticising the views of Weissmann and others, goes on to give his own theoretical opinion; viz., "that in sexual reproduction we must recognize a remedy against the action of injurious variability." He then goes on to show that disease or injurious variation of any kind in an individual would be indefinitely continued by non-sexual modes of reproduction, but in sexual reproduction is quickly eliminated by crossing with other strong and healthy individuals. Now, precisely. this view is very distinctly brought out in my article on genesis of sex. Referring to the reasons for the introduction of sexual reproduction, I say (p. 177), "The reason is probably this: Among all the qualities, good and bad, strong and weak, inherited (by the offspring) from both sides, there is a sort of struggle for life, and a survival of the best and strongest qualities.". The same thought is expressed in many ways in my book on evolution, already referred to.

Berkeley, Cal., April 24.

JOSEPH LECONTE.

\section{Catching Fixed Forms of Animal Life on Transparent Media for Study.}

IN studying forms of animal life that become fixed to foreign bodies during their early stages of development, it is an obvious advantage to the investigator if they can be induced to attach themselves to transparent media, such as glass or mica, so that they may be studied without disturbance under the microscope with transmitted light.

Several attempts have been made to secure young oysters on glass by Prof. John A. Ryder, ${ }^{1}$ Dr. R. Horst, ${ }^{2}$ and Lieut. Francis C. Winslow, ${ }^{3}$ but with only very partial success. Professor Ryder once found larvæ attached to the glass sides of an apparatus in which artificial propagation was being carried on. Dr. R. Horst tried ground and plain glass, but secured only two on the latter. Prof. Karl Möbius, in the Zoologischer Anzeiger of Jan. 22, I883, describes a successful attempt to catch fixed organisms on glass. He used microscope-slides, and secured annelids, hydroids, polyps, Bryozoa, Infusoria, diatoms, etc. Prof. B. H. Van Vleck informs me that he habitually secures fixed forms of low organisms on glass microscope-slides tor study.

During the summer of 1887 , I was studying the development of the oyster (O.virginiana Lister) at Buzzard's Bay; and as I was anxious, if possible, to get them growing on glass, I tried several methods to accomplish the desired end. During my work I had very valuable assistance and suggestions from Dr. E. B. Larchar of Onset, whose disinterested aid I here acknowledge.

In a small pond-like estuary, bare at low tide, on the 14 th of July, I stretched wire netting between stakes driven into the sand and raised about a foot from the sand. On this were laid panes of $\mathrm{g}$ lass, fastened in place with clothespins. Other panes were suspended from the sides, some in the plane of motion of the incoming tide, others opposed to it. Lamp-chimneys were also suspended from the apparatus. I used some fifty panes and twelve chimneys,

I J. A. Ryder, On the Mode of Fixation of the Fry of the Oyster (Bull. U.S. Fish Com., ii. 1882); An Account of Experiments in Oyster-Culture, and Observation relating Thereto (Rep. U.S. Fish Com., 1882), Washington, r884.

2 R. Horst, On the Development of the Oyster, O. edulis L. (Rep. U.S. Fish Com., 188 4), Washington, $\mathbf{x} 886$.

3 F. C. Winslow, Notes upon Oyster Exṕeriments in $188_{3}$ (Bull. U.S. Fish Com. iv. 1884). but met with almost total failure, securing only two oysters, one of which, however, grew to twenty-one millimetres in diameter. A few barnacles became attached to the glass.

One of the most successful spatting-grounds for oysters at Buzzard's Bay is a sand-spit exposed about four hours at low water. Here the incoming tide divides, one branch flowing to Onset, and the other to Buttermilk Bay. The force of the current is very great. On this bar, at the suggestion of Dr. Larchar, earthenware drain-pipes were partially sunk in an upright position, and loosely filled with broken glass. Six-inch and four-inch pipes were used, and at different elevations above the sand. I did not secure any spat in the four-inch pipes. A six-inch pipe sunk nearly to the level of the bar was successful, but in an unlucky dày was filled up with sand, and the young oysters buried. Six-inch pipes, reaching about ten inches above the bar, were the most successful, and on the glass in them I got large numbers of young oysters. Suitable conditions for the success of the undertaking were therefore as follows: (I) a strong tide-way, which would bring plenty of freeswimming fry, and afterwards abundant food for their maintenance; (2) an area of quiet water within the pipe, in which the fry could settle and attach themselves to the smooth glass; (3) the absolute shutting-out of violent currents which would detach them from their precarious abiding-places.

I first found spat on the glass on the 25th of July, and on the 28 th took out a pane 6 by $4 \frac{1}{2}$ inches square, on which I have just counted eighty-two young oysters, as it is still in my possession intact. This was only exceptional in the size of the glass, as other pieces bore nearly or quite as many spat proportionally to their area. Spat were secured in the pipes until the 29th of October, when few were left, large numbers having dropped off by the natural dissolving action of sea-water upon the organic cement by which they are attached.

Besides oysters, Anomias, Crepidulas, and Bryozoa freely attached themselves to the glass, presenting admirable opportunities for studying them alive and undisturbed.

The nature of my researches required that I should get young oysters with shells as clean and perfectly preserved as possible. In May, year-old oysters were found very beautifully preserved on the inside whorls of a dead Busycon shell, where they were completely protected from all eroding action, and clean. To imitate these conditions, in the salt-pond above referred to, I suspended a large number of two-and-a-half and three inch flower-pots inverted, from galvanized wire stretched between stakes driven firmly into the sand. The pots were raised about six inches from the sand. They met with entire success. The pots in many instances were literally almost covered with spat. On the outside of the pots very little, and on the inside no, sediment was deposited, as the pots hung like suspended bell-jars, so that the oysters were perfectly clean and very finely preserved. Further, on account of the porosity of the earthenware, the oysters had less hold than on natural cultch of stones and shells, and were easily removed for study.

Cambridge, Mass., May 4. ROBERT T. JACKSON.

\section{Answers.}

3I. Blonde AND BRUnetTe. - A week or two ago a correspondent of yours complained of the lack of precision of meaning attached to the terms 'blonde' and 'brunette,' and the want also of words treating of intermediate shades of color as applied to the hair and complexion of Caucasian human beings. There is certainly a need of more convention on this point ; for it seems strange that lower animals, and even inanimate objects (vide dry-goods, etc.), should be minutely characterized as regards color, whilst their lords or makers are not. It would seem as if a century and a half ago there was such better understanding about terms of color as this gentleman wishes to see established. In the Spectator one meets with proof of this. In one place I remember a lady (assumed) writer draws the distinction between herself and a friend in the matter of complexion as between an olive and a brunette; and the term 'a handsome black man' (to imply the latter hue in a man) is also met with in the writings of the last century.

St. Paul, Minn., May 3. 